\title{
Effect of Pre-Fermentative Strategies on the Composition of Prieto Picudo (Vitis vinífera) Red Wines
}

\author{
Mihaela Mihnea1,2, María Luisa González-San José1*, María Teresa Velasco-López1, \\ María Dolores Rivero-Pérez ${ }^{1}$, Miriam Ortega-Heras ${ }^{1}$, Silvia Pérez-Magariño ${ }^{3}$ \\ ${ }^{1}$ Department of Food Science and Biotechnology, Faculty of Science, University of Burgos, Burgos, Spain \\ ${ }^{2}$ Department of Viticulture and Enology, Stellenbosch University, Stellenbosch, South Africa \\ ${ }^{3}$ Instituto Tecnológico Agrario de Castilla y León, Consejería de Agricultura y Ganadería, Valladolid, Spain \\ Email: mihaela@sun.ac.za, *marglez@ubu.es
}

How to cite this paper: Mihnea, M., José, M.L.G.-S., Velasco-López, M.T., Rivero-Pérez, M.D., Ortega-Heras, M. and Pérez-Magariño, S. (2016) Effect of Pre-Fermentative Strategies on the Composition of Prieto Picudo (Vitis vinifera) Red Wines. Open Access Library Journal, 3: e3197.

http://dx.doi.org/10.4236/oalib.1103197

Received: November 3, 2016

Accepted: November 26, 2016

Published: November 29, 2016

Copyright $\odot 2016$ by authors and Open Access Library Inc.

This work is licensed under the Creative Commons Attribution International

License (CC BY 4.0).

http://creativecommons.org/licenses/by/4.0/

\begin{abstract}
The actual wine global market presents the risk of standardization of the wines and the losses of wine grape peculiarities. To combat this fact, autochthonous wine grapes are extremely interesting to use for winemaking. The use of the pre-fermentative maceration technique in autochthonous grape varieties could be an alternative of increasing their complexity. The aim of the present work was to compare the effect of five different pre-fermentative maceration treatments on the colour, phenolic and volatile composition of Prieto Picudo (PP) autochthonous red wines. The evolution during 12 months of the different wines was also studied for one vintage. Enzymatic, refrigerate and cryo-maceration treatments were applied to PP autochthonous grape varieties. The study was carried out during two consecutive vintages. Results showed that enzymatic maceration was the most effective treatment to improve levels of phenols, colour intensity and volatile compounds. Cold maceration showed also good effects. However, it was not able to improve the extractive effects of enzymatic macerations. Generally, wines obtained with pre-fermentative maceration techniques showed better colour and volatile stability than control wines.
\end{abstract}

\section{Subject Areas}

Agricultural Science

\section{Keywords}

Pre-Fermentative Maceration, Red Wine, Prieto Picudo, Phenols, Colour, Volatiles 


\section{Introduction}

The grape-wine viticultural heritage was drastically reduced during the last century, and many autochthonous varieties were lost. During the last two or three decades, the global market favoured the diffusion of a reduced number of grape varieties all over the world with the high risk of standardisation and losses of peculiarities of the wines. To combat this risk, autochthonous varieties become more important, and oenologist and wine experts try to recover certain varieties with demonstrable oenological potential [1] [2] [3]. Prieto Picudo (PP) is an autochthonous Spanish red grape (Vitis vinifera) with an intense dark colour, which is mainly cultivated in the North-West of Spain, and it is the main grape variety used to make the wines under the registered Denomination of Origen (DO) of "Tierra de Leon". Red wines from this variety are considered to have similar characteristics to Tempranillo with deep colour and marked aroma and have been poorly studied until recently. San-Juan et al. [4] analysed some uncommon thiols in PP red wines, while other authors have published some recently data on PP rosé wines [5] and sparkling wines [6] [7].

It is well known that volatile and phenolic compounds contribute strongly to the quality of red wines and the composition of the wine for these compounds is affected by different factors. Their levels in wine depend on the grape composition, the pre-fermentative and fermentative techniques but also on the storage conditions. Due to the fact that phenolic compounds and aroma precursors are mainly located in the solid parts of the grapes [8], all strategies that can increase their extraction are potentially useful to increase the quality of wines.

The enzymatic maceration has been demonstrated to be one of these strategies, and nowadays is the oenological maceration technique most widely applied to make rosé and red wines. There are a large number of commercial products, which usually contain pectinase, cellulase and hemicellulase activities that degrade the cellular-walls improving the extractability of phenols and aroma precursors [9] [10]. These products have been extensively used to increase the extraction of phenols, especially of anthocyanins [11] [12] [13]. Wines with intense and stable colour, as well as with a pleasant structure and mouthfeel have been obtained by applying extractive enzymes [14] [15] [16]. However, other authors did not note these positive effects [17] [18]. The discrepancies among published results are related to the variability among grape varieties, as well as to the degree of ripeness of the grapes and the structure of the grape skin [19]. The degradation of cellular walls by extractive enzymes also favours the extraction of aromatic compounds and certain aroma precursors [20] [21] [22]. Moreover, some authors have detected glycosidase activity in some commercial products [20], which favours the breakdown of aromatic precursors (without any smell) and intensifies the aromatic content of wines. This fact is beneficial to white wines [23], but not to red and rosé ones, due to the degradation of pigments induced by the glycosidase activity [24].

From the late 90 's, and especially from the beginning of this century, cold pre-fermentative maceration has also been used to assist with both the extraction of aroma precursors and that of phenolic compounds. Wines with greater colour and body as 
well as with a more complex aromatic profile, have been obtained applying this methodology; [20] [25] [26] [27] [28]. The pre-fermentative cold maceration is when one maintains the crushed grapes at low temperatures (below $4^{\circ} \mathrm{C}$ or $8^{\circ} \mathrm{C}$ ) for variable periods. During this time, the maceration of the solids takes place with the must, assisting the preferential extraction of hydrosoluble compounds of the grape such as anthocyanins, free aromas, various aromatic precursors, polysaccharides and glycosylated phenols. The desired temperature of the grapes can be achieved by storing them in a cool room, using heat exchangers, or by using cryogenic agents such as dry ice. The former two systems are used for the so called refrigerated maceration, while the maceration with cryogenic agents is called cryo-maceration. Dry ice is the most widely used cryogenic agent because it combines various effects: blocking the start of fermentation by lowering temperatures, the partial freezing of grapes which produces the breakdown of vegetal tissues and a cellular disorganization of skin and pulp improving the extraction of compounds of interest; and displacement of oxygen with the consequent protective effect against the oxidative degradations [25] [29] [30]. In addition, the effect of cold produces a thermal shock that inhibits the action of various oxidative enzymes [31]. This fact, together with the anaerobic ambient avoid enzymatic degradation of pigments and volatile compounds. Pre-fermentative cold maceration has been applied successfully in the vinification of red grapes with low levels of polyphenols and anthocyanins, such as Pinot Noir [27], but also in the vinification of grapes with a high phenolic content, such as Sangiovese [29].

The present work shows a comparative study of various pre-fermentative maceration techniques-enzymatic maceration, refrigerated maceration and cryo-maceration using dry-ice pellets-as opposed to traditional vinification. The study was focused on the effects of pre-fermentative maceration techniques on phenolic, colour, antioxidant capacity and volatile composition of red wines made with Prieto Picudo Vitis vinifera grapes. This study was carried out during two consecutive vintages, and additional measurements were taken to test the storage effect over the last year of the study.

\section{Materials and Methods}

\subsection{Reagents and Standards}

Gallic acid, catechin, caffeic acid, quercetin, 2,2'-azinobis 3-ethylbenzothiazoline-6sulfonic acid (ABTS), 6-hydroxyl-2, 5, 7, 8-tetramethyl-2-carboxylic acid (TROLOX), 2,4,6-Tris (2-pyridyl)-S-triazine) (TPTZ), 2-deoxy-D-ribose, dichloromethane (HPLC grade) were used from Sigma-Aldrich Co (Quimica S.A, Madrid, Spain).

Chemical standards used for gas chromatography quantitative analysis were purchased from different companies: isobutyl alcohol, isoamyl acetate, ethyl hexanoate, hexyl acetate, 3-methyl-1-pentanol, 1-hexanol, ethyl 3-hydroxy butanoate, diethyl-2hydroxy-glutarate, $\beta$-phenylethyl acetate, diethyl succinate, isoamyl lactate, phenylethyl lactate, isovaleric acid, hexanoic acid, octanoic acid, decanoic acid and dodecanoic acid from Fluka (Quimica S.A, Madrid, Spain); 2,3-butanediol, 1-octanol, benzyl alcohol, 2-phenylethyl alcohol, trans-3-hexen-1-ol, methionol, ethyl butanoate, ethyl lactate, 
ethyl octanoate, ethyl decanoate, ethyl dodecanoate, $\alpha$-terpineol, $\beta$-citronellol, linalool, geraniol, nerol, $\gamma$-nonalactone and 4-ethoxycarbonyl- $\gamma$-butyrolactone from Aldrich (Quimica S.A, Madrid, Spain); isoamyl alcohol, cis-3-hexen-1-ol, benzaldehyde, and $\gamma$-butyrolactone from Sigma (Quimica S.A, Madrid, Spain).

Hydrogen, Nitrogen, Helium and Air gases were provided by CarburosMetalicos (Barcelona, Spain).

Potassium persulfate, ferric (III) chloride acid, hydrogen peroxide, L-ascorbic acid and trichloroacetic acid (TCA) were obtained from Panreac (Barcelona, Spain). Thiobarbituric acid (TBA) and formic acid was purchased from Merck (Darmastadt, Germany). TRIS and EDTA tetrasodium salt, from Amresco (Ohio, USA). Methanol from Lab-Scan (Dublin, Ireland). Malvidin-3-glucoside from Extrasynthèse (Lyon, France).

\subsection{Samples}

The different wines were obtained in the experimental pilot plant of the Department of Food Technology (University of Burgos, Spain). Healthy grapes of the Prieto Picudo red variety were collected in a vineyard situated in the Protected Denomination of Origin "Tierra de Leon" area. The grapes were harvested in the same vineyard over two consecutive vintages. They were harvested in the early morning and immediately transported to Burgos, in $15 \mathrm{Kg}$ plastic boxes. Each vintage, after reception, the grapes were randomly divided into twelve groups of $35 \mathrm{Kg}$ of grapes, two groups of $35 \mathrm{Kg}$ grapesfor each treatment under study.

Control wines (C): grapes were destemmed, slightly crushed and sulphited (40 $\mathrm{mg} / \mathrm{Kg} \mathrm{SO}_{2}$ ), and then placed in stainless steel tanks to carry out the alcoholic fermentation, which was induced by commercial yeast, Saccharomyces cerevisiae (Excellence spLamothe-Abiet, France) inoculated in the doses recommended by the supplier. Alcoholic fermentation was carried out at $25^{\circ} \mathrm{C}-28^{\circ} \mathrm{C}$ until residual sugar level was lower than $3 \mathrm{~g} / \mathrm{L}$. After 12 days of maceration, wines were racked off to clean stainless steel tanks, where were mixed with first pressure wines, and then lactic acid bacteria Oenococcusoeni (Viniferm Agrovin, Spain) were inoculated to induce malolactic fermentation, which was carried out at $20^{\circ} \mathrm{C} \pm 2^{\circ} \mathrm{C}$. Once the malolactic fermentation finished(malic acid $<0.03 \mathrm{~g} / \mathrm{L}$ ), wines were racked off once more to clean tanks, where they were clarified by natural decanting favoured by low temperatures $\left(<7^{\circ} \mathrm{C}\right)$. This process was carried out in a cool room. Wines were bottled without any filtration process. Some bottles were stored under controlled temperature $\left(\approx 12^{\circ} \mathrm{C}\right)$ for one year. Wines were analysed by triplicate (tree bottles by batch).

Wines from maceration treatment were made in similar way to the control wines with the exception of the pre-fermentative maceration steps.

Enzymatic macerationwines (E), 3 g/HL of pectolytic enzymes (Vinozym FCE, Novozymes, France) were added to the crushed grapes before the inoculation of yeast, which was retarded around eight hours, to favour the enzymatic action before the beginning of the alcoholic fermentation.

$\underline{\text { Refrigeration wines }(\mathrm{R})}$ were made from groups of grapes that had previously been 
refrigerated, in a cool room, until raised $5^{\circ} \mathrm{C}$. Cold grapes were destemmed, slightly crushed and sulphited, similarly to previous cases, and the crushed grapes were maintained at $5^{\circ} \mathrm{C}$, in the cool room, for 3 or 7 days (R3 and R7) to carry out refrigerated maceration. At the end of maceration time, crushed grapes were put into stainless steel tanks; the temperature was increased until $20^{\circ} \mathrm{C}$ and then, yeasts were inoculated to make alcoholic fermentation.

Cryo-maceration wines (CM) were made in a similar way to $\mathrm{R}$ wines, but the temperature of $5^{\circ} \mathrm{C}$ of crushed grapes was achieved and maintained by adding $3 \mathrm{~mm}$ dry ice pellets. Maceration times of 3 and 7 days (CM3 and CM7) were also studied.

\subsection{Analytical Methods}

The main oenological parameters ofwines: $\mathrm{pH}$, titratable and volatile acidity, reducing sugars and alcohol degree, were analysed according to OIV methods [32].

Total polyphenol content (TP, expressed as $\mathrm{mg} / \mathrm{L}$ of gallic acid), total anthocyanin content (Acy, expressed as $\mathrm{mg} / \mathrm{L}$ of malvidin-3-glucoside), and levels of total catechins (Cat, expressed as $\mathrm{mg} / \mathrm{L}$ of $\mathrm{D}$-catechin) were evaluated by classical spectrophotometer methodologies [33]. Furthermore, total flavonol contents (Flav, quantified as mg/L of quercetin) and total tartaric ester levels (Tar-Est, expressed as mg/L of caffeic acid) were analysed according to Mazza et al. [34]. Total tannin levels (Tan) were quantified as $\mathrm{g} / \mathrm{L}$ of gallic acid [35]. Wine colour was evaluated by the Glories parameters: colour intensity (CI), tonality (To), percentage of yellow (\%Yellow), percentage of red (\%Red) and percentage of blue (\%Blue) [36]. The contents of individual anthocyanins were determined by HPLC in an Agilent Technologies LC Series 1100, with a diode-array detection system, and the Pérez-Magariño and Gonzalez-Sanjose [37] method was used. Data on anthocyanin glucosides (AcyGls) (delphinidin, cyanidin, petunidin, peonidin, and malvidin-3-glucosides), acetylated anthocyanins (Acy Ac) (delphinidin, cyanidin, petunidin, peonidin, and malvidin acetyl-3-glucosides), cinnamylatedanthocyanins (AcyCin) (delphinidin, petunidin, peonidin, and malvidin coumaryl-3-glucosides, and malvidin caffeyl-3-glucoside) and pyruvic acid derivatives of delphinidin, petunidin, and malvidin 3-glucoside (AcyPir) were considered in this study. All anthocyanins were quantified as equivalents of $\mathrm{mg} / \mathrm{L}$ of malvidin-3-glucoside, applying the respective external standard calibration curve.

The volatile compounds were extracted and analysed according to methodology described by. Ortega-Heras et al. [38] that was slightly modified. They were extracted with dichloromethane ( $250 \mathrm{~mL}$ wine $/ 5 \mathrm{~mL}$ dichloromethane). Analyses were carried out by direct injection of $1 \mu \mathrm{L}$ of dichloromethane extract into a 7890A GC System Agilent Technologies (Agilent technologies S.L, Madrid, Spain), with a FID detector. A Carbowax $20 \mathrm{M}$ column $(60 \mathrm{~m} \times 0.32 \mathrm{~mm}, 0.25 \mu \mathrm{m}$ film thickness), from Quadrex Corporation (Symta, Madrid, Spain), was used. The oven column program was set at $40{ }^{\circ} \mathrm{C}$ and held for 8 minutes, then raising to $85^{\circ} \mathrm{C}$ at $10^{\circ} \mathrm{C} / \mathrm{min}$ and held for 1 minute, then raised again to $230^{\circ} \mathrm{C}$ at $2^{\circ} \mathrm{C} / \mathrm{min}$ and held for 35 minutes.

Compound identification was performed by recording the relative retention time of 
the standards in relation to the internal standard (2-octanol) and by verifying the MS spectrum using a 5973 GC-MS equipment (Agilent Technologies) and the NIST library. Quantification was performed using the internal standard method (2-octanol) and the corresponding calibration curves for each quantified compound, expressed in mg/L. 39 volatile compounds were quantified, the data on which will be discussed by groups according to their chemical families. The next groups of compounds were considered: fusel alcohols (isobutyl alcohol, isoamyl alcohol, 2-phenylethyl alcohol), other alcohols (2,3 butanediol, 3-methyl 1-pentanol, 1-octanol, benzyl alcohol), C6 alcohols (1-hexanol, trans-3-hexen-1-ol, cis-3 hexen-1-ol), acetates (isoamyl acetate, hexyl acetate, $\beta$ phenylethyl acetate), ethyl esters (ethyl butanoate, ethyl 3-hydroxy butanoate, ethyl lactate, ethyl hexanoate, ethyl octanoate, ethyl decanoate, ethyl dodecanoate, diethyl succinate, diethyl-2-hydroxyl-glutarate), lactates (isoamyl lactate, $\beta$-phenyl-ethyl lactate), fatty acids (isovaleric acid, hexanoic acid, octanoic acid, decanoic acid, dodecanoic acid), lactones (4-ethoxycarbonyl- $\gamma$-butyrolactone, $\gamma$-butyrolactone, $\gamma$-nonalactone) and terpenes ( $\alpha$-terpineol, $\beta$-citronellol, nerol, linalool, geraniol). Furthermore, benzaldehyde and methionol were also considered, but as individual compounds.

Total antioxidant capacity was evaluated by ABTS and FRAP, and scavenger activity was carried out using deoxyribose assay (HRSA), all of them according to the optimized methods described by Rivero-Pérez et al. [39].

\subsection{Statistical Analyses}

The analysis of the variance (ANOVA) and the Least Significant Difference test (LSD) were used to detect differences and to establish the values which can be considered statistically different at $p<0.05$. Multivariate analyses were applied to find natural groups. Factorial Analysis by Principal Components was chosen. Varimax criteria were applied to factor rotation and eigenvalues over unit were applied as the criteria to select the number of final factors to be considered.

\section{Results and Discussion}

The analysis of the wines showed some significant effects of maceration treatments on the composition of the final wines so in their stability during storage, as it will be shown below.

The pre-fermentative maceration treatments under study modified the phenolic composition of the wines. From the point of view that oenological classical parameters of all obtained wines were very similar among them (Table 1), the observed extractive effects should be attributed to the maceration treatment and not to the alcohol degree or the $\mathrm{pH}$ of the medium.

Generally, wines from enzymatic maceration (E) showed the highest levels of phenolic compounds, this was equalled only one year by the wines obtained from the 7 days cold maceration (Table 1). The enzymatic maceration had a stronger effect in the first year when the total polyphenol level of the wines was increased by $16 \%$ while in the second year it was increased by around $7.5 \%$. Furthermore, in the first year tannin lev- 
Table 1. Oenological parameters, phenolic composition, colour parameters and antioxidant activity of studied Prieto Picudo wines at bottling.

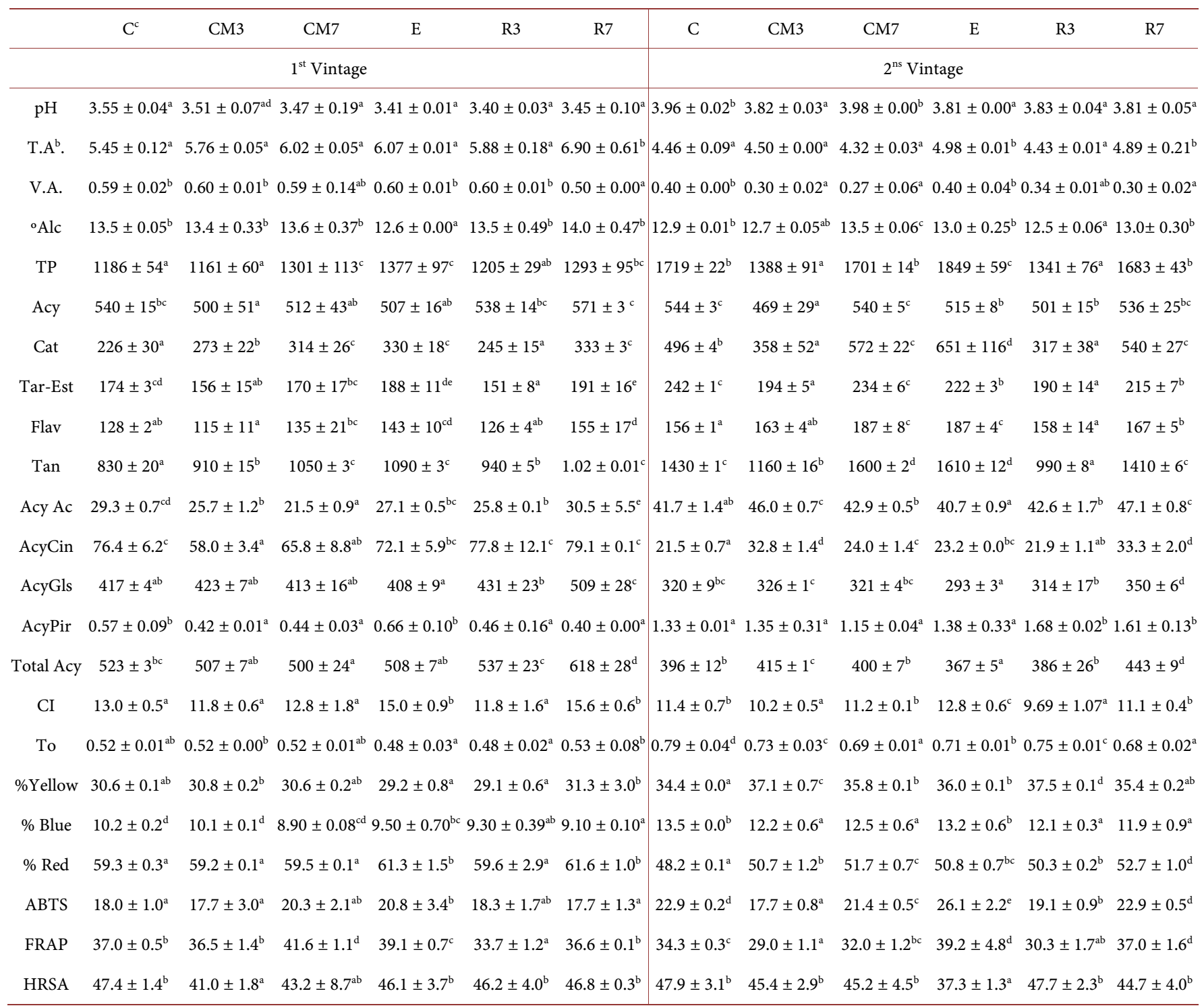

${ }^{\mathrm{a}}$ Mean values \pm standard deviation. $\mathrm{N}=6$ ( 2 different winemaking by studied treatment $\times 3$ different bottles analysed by treatment and sample time); ${ }^{\text {b T.A: }}$ titratable acidity (g/L tartaric acid); V.A: volatile acidity (g/L acetic acid); ${ }^{\circ}$ Alc (Alcoholic degree $\%$ vol); TP: total polyphenol content (mg/L gallic acid); Acy: total anthocyanin content (mg/L malvidin-3-glucoside); Cat: total catechins (mg/L D-catechin); Flav: total flavonol content (mg/L of quercetine); Tar-Est: total tartaric ester levels (mg/L caffeic acid); Tan: Total tannins (mg/L gallic acid); CI: colour intensity; To: tonality; Acy: anthocyanins, Ac: acetylated, Cin: cinnamylated, Gls: glucosides, Pir: pyruvic acid derivative (all of them mg/L malvidin-3-glucoside); ABTS (mM of Trolox) and FRAP (mMFeII); HRSA: scavenger activity against hydroxyl radical (\% Inhibition); ${ }^{\mathrm{C}} \mathrm{C}$-control; E-enzyme; $\mathrm{CM}$-cryo-maceration; R-refrigeration; 3 and 7 duration of maceration (days). ${ }^{\mathrm{d}}$ The different letters by rows and vintage indicate significant differences among values at $p<0.05$.

els of the wines from enzymatic maceration increased by around $31 \%$, and catechin levels by around $46 \%$, while in the wines of the second vintage the increases were around $13 \%$ and $31 \%$, respectively (Table 1 ). These results seem to be well correlated with different degrees of ripening of the grapes of the first and second vintages, which showed values of the sugar/acidity ratio (classical ripening index) around 28 and 30 , respectively. According to the maturity index, less mature grapes from first vintage had a 
lower phenolic content (4.7 as against $7.9 \mathrm{~g}$ of gallic acid by $\mathrm{kg}$ of fresh grapes), and also showed higher resistance to the extraction due to their thicker skins (visual observation and higher weight: $139 \mathrm{~g} / 100$ grapes from first vintage comparing to $108 \mathrm{~g} / 100$ grapes from second vintage). Previous papers also noted that maceration techniques are more effectives when they are applied on less ripening grapes than on mature grapes [12] [14] [18] [40] [41] [42].

The different ripening degree of the grapes of each vintage was reflected especially on the composition of the control wines, which showed significant differences in a lotof the variables under study (Figure 1). The higher levels of phenolic compounds of the wines of the second vintage were well correlated with the higher content of phenolic compounds of the grapes of this vintage (levels of: total polyphenols 7.9 as against $4.7 \mathrm{~g}$ of gallic acid by $\mathrm{kg}$ of fresh grapes; total anthocyanins 6.6 as against $4.4 \mathrm{~g}$ of malvidin3 -glucoside by $\mathrm{kg}$ of fresh grapes; total catechins 1.6 as against $0.4 \mathrm{~g}$ of $\mathrm{D}$-catechin by $\mathrm{kg}$ of fresh grapes; tartaric esters 0.07 as against $0.05 \mathrm{~g}$ of caffeic acid by $\mathrm{kg}$ of fresh grapes).

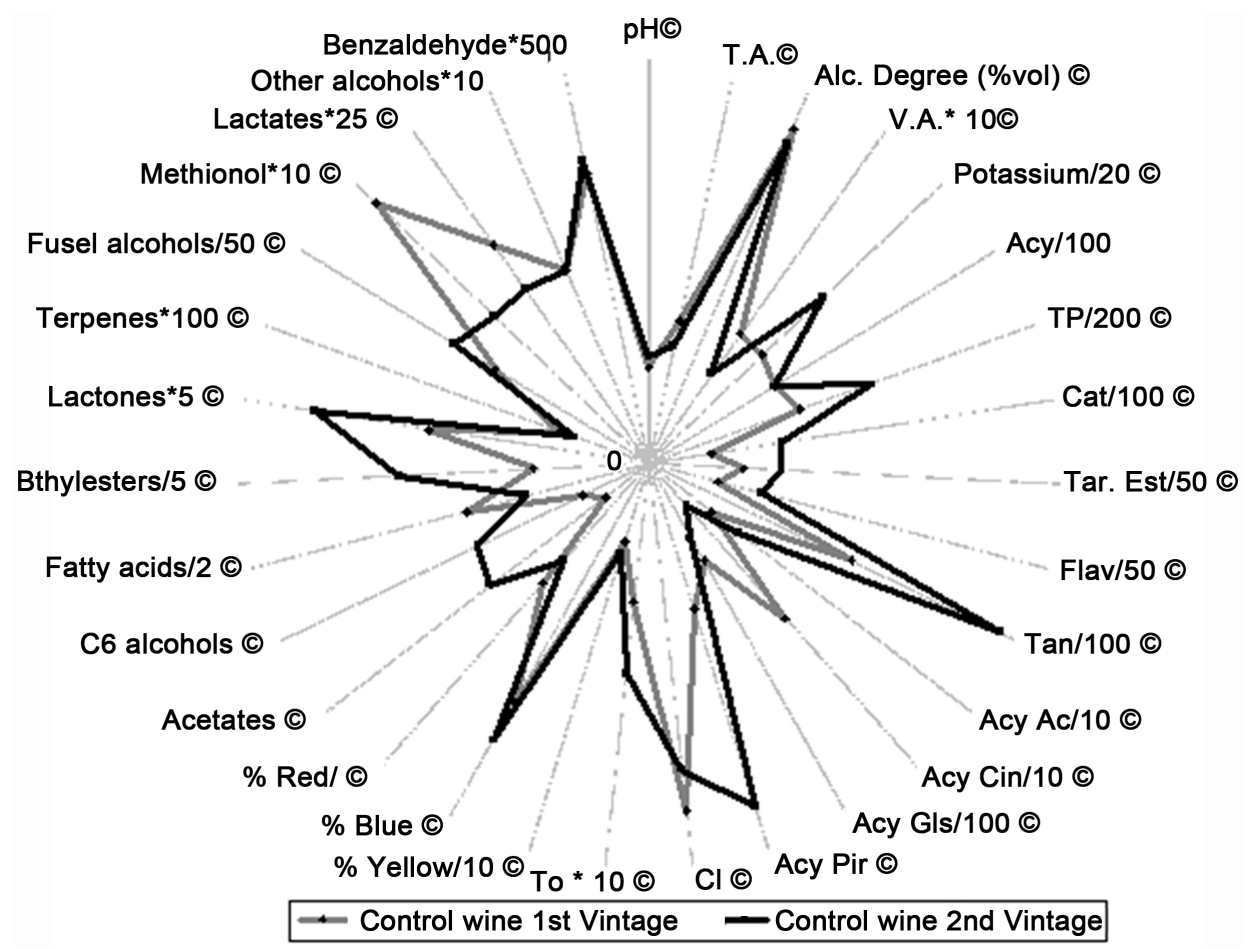

Figure 1. Mean values of the parameters evaluated on Prieto Picudo control wines of both vintages. $\mathrm{N}=6$ ( 2 different winemaking by studied treatment $\times 3$ different bottles analysed by treatment and sample time). Symbols $(* /)$ and numbers alongside each variable name indicate a scaling factor that permits the use of a similar range of values for all variables. $\odot=$ values with statistical differences. T.A: titratable acidity (g/L tartaric acid); V.A: volatile acidity (g/L acetic acid), TP: total polyphenol content (mg/L gallic acid); Acy: total anthocyanin content $(\mathrm{mg} / \mathrm{L}$ malvidin-3-glucoside); Cat: total catechins (mg/L D-catechin); Flav: total flavonol content (mg/L of quercetine); Tar-Est: total tartaric ester levels (mg/L caffeic acid); Tan: Total tannins (mg/L gallic acid); CI: colour intensity; To: tonality; Acy Ac: acetylated anthocyanins; AcyCin: cinnamylatedanthocyanins; AcyGls: anthocyanin glucosides and AcyPir: pyruvic acid derivative anthocyanins (all of them $\mathrm{mg} / \mathrm{L}$ malvidin-3-glucoside). 
The effects of pre-fermentative cold macerations, refrigeration and cryo-maceration, were shown to be "time dependent", especially in the first year, so the effect was clearly different depending on the length of the maceration. In some cases, short macerations did not improve extraction, and even worsened this process (Table 1). Similar results were not previously published, although they were accrued out with other varieties [25] [43] [44] [45]. The reduction of phenol levels in wines that underwent cold maceration for a short time could be due to some blockage of the extraction due to the partial freezing of the crushed grapes, or to the typical slowdown of extractive procedures to low temperatures.

Levels of total anthocyanins were not increased by maceration techniques (Table 1). Moreover, lower values for these pigments were frequently observed in maceration wines, especially in wines from enzymatic maceration. Similar results have previously been described [17] [46] [47], and usually the drop in levels of total and monomeric anthocyanins was explained by the formation of larger amounts of condensation and polymerisation pigments.

The wines made with enzymatic maceration showed the highest values for colour intensity (Table 1). These data agree with those found but many other authors [11] [20] [48] and agree with data of phenolic composition. Furthermore, the obtained values of ABTS, FRAP and HSRA (Table 1) were wellcorrelated with the phenolic content of the wines, and agree with the antioxidant capacity of wines described previously by other authors [39] [49] [50] [51].

The effects of the maceration treatments under study on the volatile composition of the wines were both qualitatively and quantitatively variable over the two years and within the treatments. The effects were at times contrary (Figure 2). Only some similar effects were detected for some specific compounds and treatments. Thus, the wines obtained with enzymatic maceration always showed qualitatively higher levels of terpenes, lactones and ethyl esters than control wines, but lower levels of methionol and some alcohols such as 2-phenylethanol, isobutyl alcohol and 1-octanol. The increase of terpenes levels agrees with the results obtained from Monastrell wines made with enzymatic maceration [22]. The lower levels of alcohols agree with results previously obtained. Gil and Vallés [20] observed lower levels of 1-octanol in red wines made with enzymatic maceration, and Hernández-Orte et al. [21] also detected lower levels of methionol and 1-octanol in macerated white wines from Macabeo grapes. The lower levels of alcohols in Albillo wines made after increasing maceration were explained by Sánchez-Palomo et al. [52] through the blocking of the Erlich mechanism, the main pathway for alcohol formation. They suggested that, according to Rapp and Versini [53], the blocking occurred due to the increasing of nitrogen compounds in the initial must. However, other authors found contrary results. Armada et al. [54] found higher levels of alcohols in Albariño wines made with enzymatic maceration; they noted especial increase forisoamyl alcohol and 2-phenylethanol levels. A higher content of esters in wines from enzymatic maceration were also found by Hernández-Orte et al. [21].

Other coincident results in both vintages were the higher levels of terpenes and acetates of the cryo-maceration wines when compared with control wines. Furthermore, 


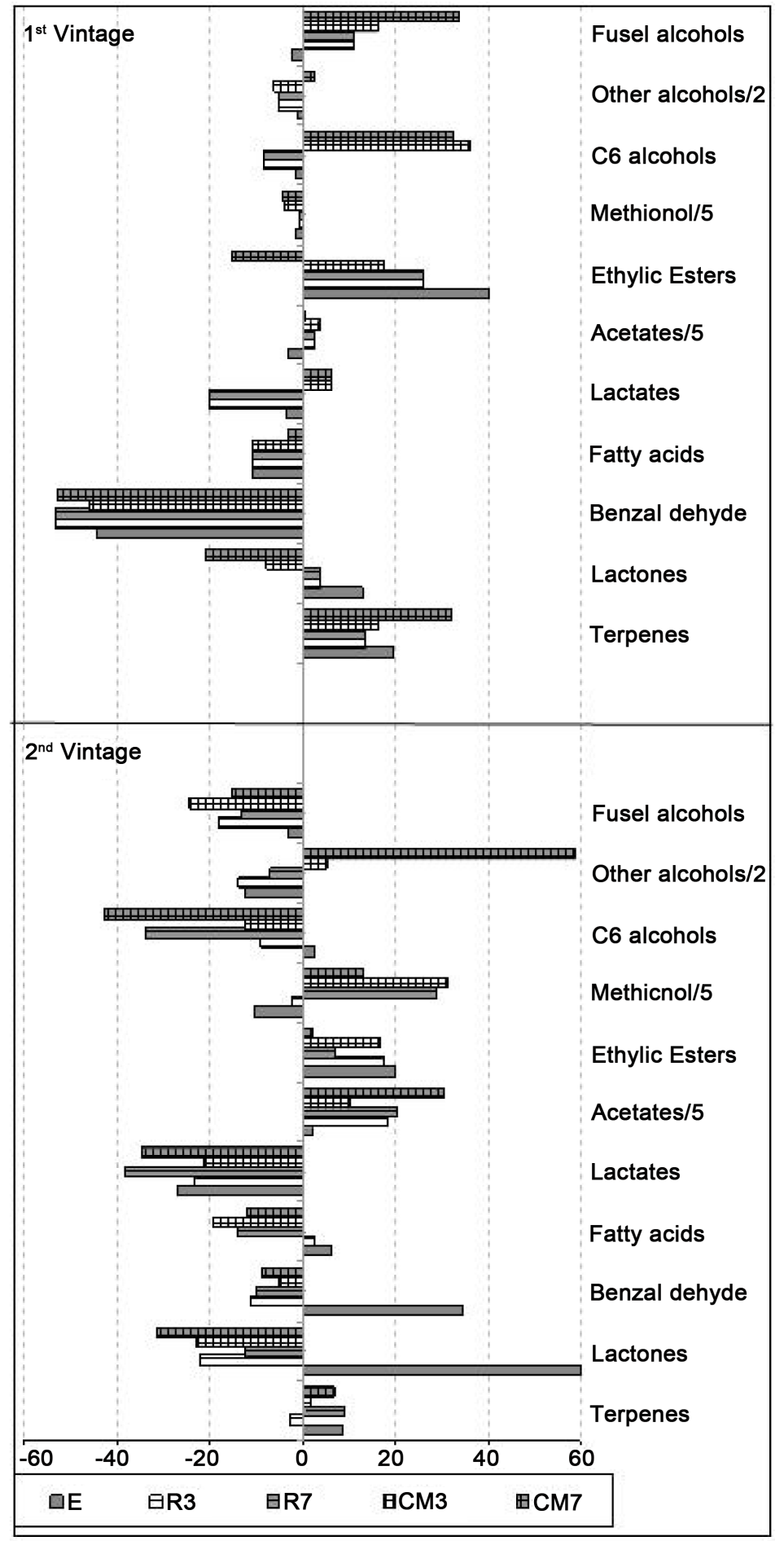

Figure 2. Effects of the different pre-fermentative maceration techniques on the volatile composition of studied Prieto Picudo wines. Columns show mean value percentage differences between the wines elaborated with each pre-fermentative maceration technique and the control wines. $\mathrm{n}=$ 6 ( 2 different winemaking by studied treatment $\times 3$ different bottles analysed by treatment and sample time). E-enzyme; $\mathrm{CM}$-cryo-maceration; R-refrigeration at $5^{\circ} \mathrm{C} ; 3$ and 7 , duration time of maceration (days). Symbol (/ and $\left.{ }^{\star}\right)$ and numbers alongside variable names indicate thefactor applied to enhance the graphic. 
these wines always showed lower levels of lactones and benzaldehyde than control wines. However, quantitatively the differences were very different each year. Previousstudies showed similar results. Thus, higher acetate levels were described by Álvarez et al. [25] and Kechagia et al. [55]; and higher levels of terpenes in wines made with cryo-maceration were found by De Santis and Frangipane [26] and Mihnea et al. [56]. However, effect on lactones levels is contrary to the results described by Álvarez et al. [5] and Mihnea et al. [56], especially due to higher levels of $\gamma$-butyrolactone in wines made with cryo-maceration.

Refrigerated maceration also showed some repetitive effect in both vintages. Macerated wines showed lower levels of lactates, benzaldehyde and other alcohols, than control wines, and in the case of R7, also showed lower levels of lactones. Moreover, R3 showed higher levels of esters than control wines in both years.

In summary, the results from the volatile compounds demonstrated that maceration techniques produced significant modifications in the volatile composition of wines; however, the results also showed that achieving the control of the specific modifications seems to be quite difficult. This fact is due to the large number of factors, which are able to influence on the final effect of maceration techniques. The experimental data of this work, as well as previous published papers, show that the degree of maturity of the grapes [25] [41], the vintage [55] [56] [57], and the variety [58] are some of the most important factors of variability.

It seems to be possible to assert that pre-fermentative cold macerations do not appear to improve the extractive effects of enzymatic macerations, which are effective for the extraction of phenols from Prieto Picudo grapes and which also have a positive effect on the extraction of certain volatiles and of their precursors. Moreover, enzymatic strategies are quicker and easier to apply than cold macerations. On the other hand, enzymatic maceration will be applied without investments in special installations such as cool rooms or dry ice containers and dispensers. Thus, a priori the enzymatic maceration seems to be the most effective and efficient strategy to improve the extraction of phenolic and volatile compounds and precursors from Prieto Picudo grapes. This technique also allows wines to be made with more colour intensity.

The majority of red wines are not consumed before the first six months after their making. For this reason, their evolution during storage is very important. It is expected that positive extractive effects of pre-fermentative maceration strategies produce significant improvement of colour stability so as of the volatile profile of the wines. However, this fact should be tested. So, the evolution of the studied parameters, during one year of bottled wines storage, was evaluated. This study was performed with wines from the second vintage, which were analysed after 6 and at 12 months of storage.

Results showed a normal evolution of phenolic compounds during the storage, as shown in Figure 3. A clear descendent tendency, which was more or less pronounced depending on the type of compound and treatment, was observed. A marked drop in the levels of total and monomeric anthocyanins was observed, as well as in tartaric esters and catechins, whereas the level of condensed pigments increased, above all after 

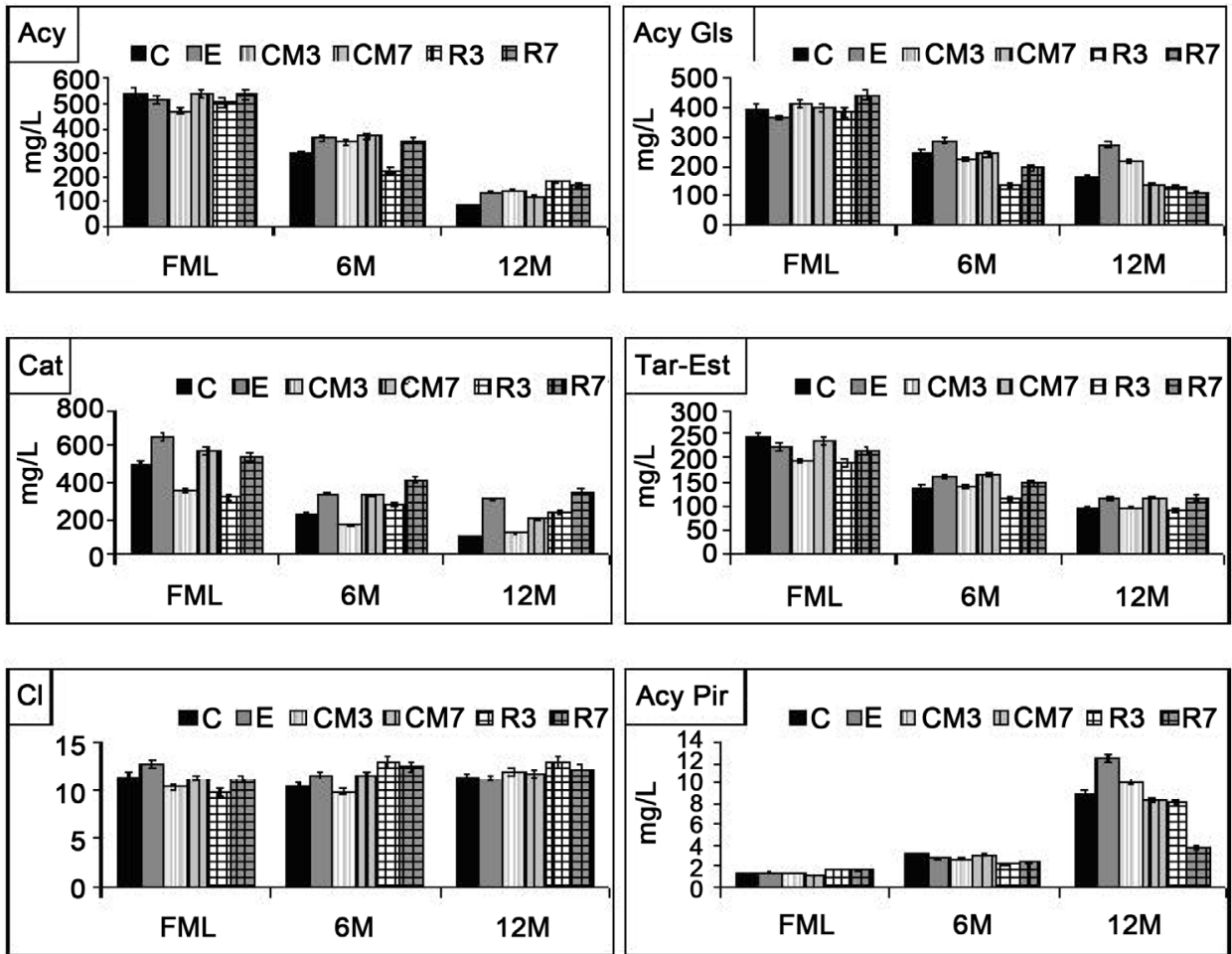

Figure 3. Phenolic composition and colour intensity evolution of the wines from the second vintage over 1 year of bottle storage. Columns shows mean values, $n=6$ ( 2 different winemaking by studied treatment $\times 3$ different bottles analysed by treatment and sample time). $6 \mathrm{M}$ and $12 \mathrm{M}=6$ and 12 months of bottle storage. FML-end of malolactic fermentation. Acy-total anthocyanin content and AcyGls and AcyPir-anthocyanin glucosides and pyruvic acid anthocyanins; Cattotal catechins (mg/L of D catechin); Tar-Est: total tartaric esters levels (mg/L of caffeic acid); $\mathrm{CI}$-colour intensity. $\mathrm{C}$-control; E-enzyme; $\mathrm{CM}$-cryo-maceration; R-refrigeration at $5^{\circ} \mathrm{C} ; 3$ and 7 , duration time of maceration (days).

12 months of storage. The chromatic intensity remained relatively constant, but from month 6 some wines from maceration treatment showed slightly superior intensities (Figure 3). These results agreewith those obtained in previous works [15] [16] [59] [60].

The global volatile composition evolved to lower levels and, in general, the decreasing tendency was more notable in the macerated wines than in control wines (Figure 4). The general reduction of the volatile content during the storage of the wines is habitual [61] [62]. However, the levels of some volatiles showed a tendency towards increasing. So, levels of ethyl esters increased significantly after 6 months of bottle storage. Similarly, levels of lactones and methionol also increased during the first six months of storage, although more slowly than ethyl ester levels. Pérez-Coello et al. [63] also observed an increase in lactones and methionol during storage of white wines. The authors explained the observed increase by the higher level of the volatile precursors in macerated wines. Therefore, in summary, it may be said that wines from pre-fermentative maceration behaved in a similar way to other wines. In general, they were richer in phenolic compounds and their colour was more stable with time. However, they had 


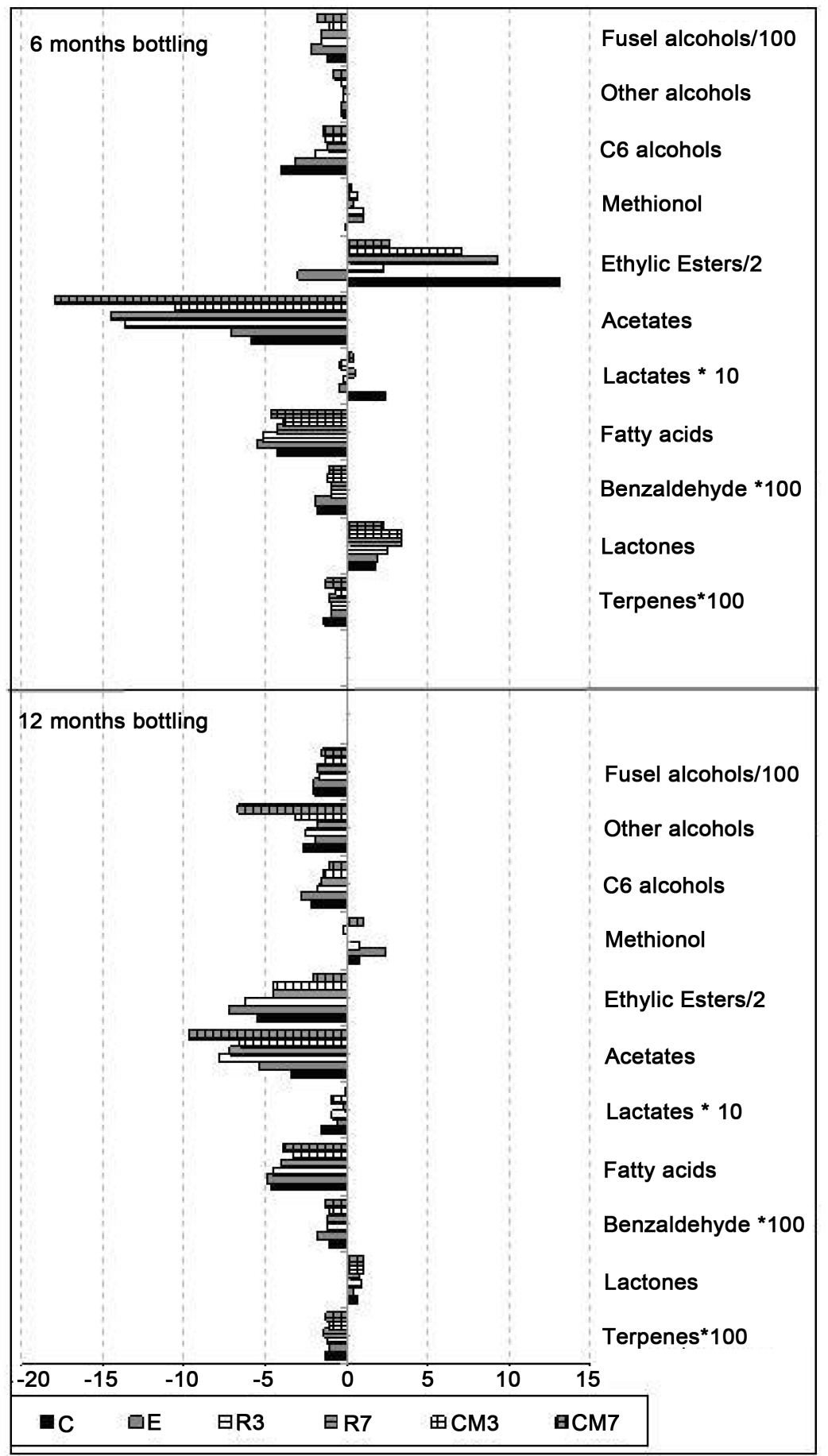

Figure 4. Changes on volatile composition of bottled Prieto Picudo wines from the second vintage during their storage. Columns represent mean values of the differences between levels $(\mathrm{mg} / \mathrm{L})$ of volatile compounds in the wines recently bottled and in the wines after 6 and 12 months of bottle storage, respectively. $\mathrm{N}=6$ ( 2 different winemaking by studied treatment $\times 3$ different bottles analysed by treatment and sample time). Symbol (/and ${ }^{\star}$ ) and numbers alongside variable names indicate the factor applied to enhance the graphic using a similar range of values for all variables. C-control; E-enzyme; $\mathrm{CM}$-cryo-maceration; R-refrigeration at $5{ }^{\circ} \mathrm{C} ; 3$ and 7 , duration time of maceration (days). 
greater drops of volatile compounds than control wines, which could be due to their higher initial levels of volatile compounds. Beside these, the effects of each maceration treatment detected on young wines remained notable enough after 12 months storage.

In order to better understand the previous commented results and to get a global view of the different techniques effects, factorial analysis was employed. Three factors were chosen to explain $74.1 \%$ of the total variance of the samples.

The distribution of the scored values of each wine on the plane defined by the two main factors (Figure 5(a)), which together explained $66 \%$ of total variance, showed that wines are grouped by age and vintage. The wines from the first vintage were positioned on the top of the figure, corresponding with higher values of factor 1 (F1). The variables with more weight in $\mathrm{F} 1$ were the content of individual anthocyanins and the chromatic parameter \%Red, with positive scores, and the chromatic parameters \%Yellow and \%Blue so as the tonality, with negative scores. Furthermore, some volatiles also were strongly associated to this factor. They were mainly fatty acids, terpenes, lactates and fusel alcohols, with positive scores, and ethyl esters and lactones, with negative scores. Wines from the first vintage showed higher levels of individual anthocyanins and higher values of the red component, with quantitative strong differences in both cases. Furthermore, they showed significant lower values of blue and yellow component, so as of tonality. The chromatic and pigment levels in both groups of wines explained perfectly the position of first vintage wines on the plane. Moreover, data from volatile composition contributed to this localization, due to the fact that first vintage wines were richer in fatty acids, terpenes and lactates, but poorer in ethyl esters and lactones. All the differences on composition and chromatic characteristics of both groups of wines were mainly attributed to the different maturity stage of the grapes of each vintage, and then F1 was considered as a "vintage" factor.

Regarding the age of the wines, the lower scores values of storage wines with respect to young wines, in both factors (F1 and F2), were associated with the drop of phenolic levels, colour changes and modifications on volatile composition that occurred during storage. Lower values of F1 were associated mainly with the drop of anthocyanin levels (Figure 3), but also with the reduction of levels of some volatiles as terpenes, fatty acids and lactates, and with the increase of the levels of others as ethyl esters and lactones (Figure 4). All these comments also explain why changes during the first six months were more notable than those occurring in the last six months.

The variables with the highest weight in factor 2 (F2) were acetates, tartaric esters, C6 alcohols and other alcohols, with positive scores, and colour intensity with negative score. The intense losses of tartaric esters (Figure 3) and of acetates (Figure 4), occurred during the first six months of storage, were the main reasons to explain the evolution of F2 values to negative zone, so the oldest wines showed the lowest values of F2.

Factor 3 (F3) associated with the rest of phenolic variables, total polyphenols, catechins, tannins and flavanols, so as the antioxidant parameters, ABTS, FRAP and HSRA, all of them with positive scores. The F3 values of wines under storage were clearly lower than those of the young wines (Figure 5(b)). Once more, the reduction of F3 values 


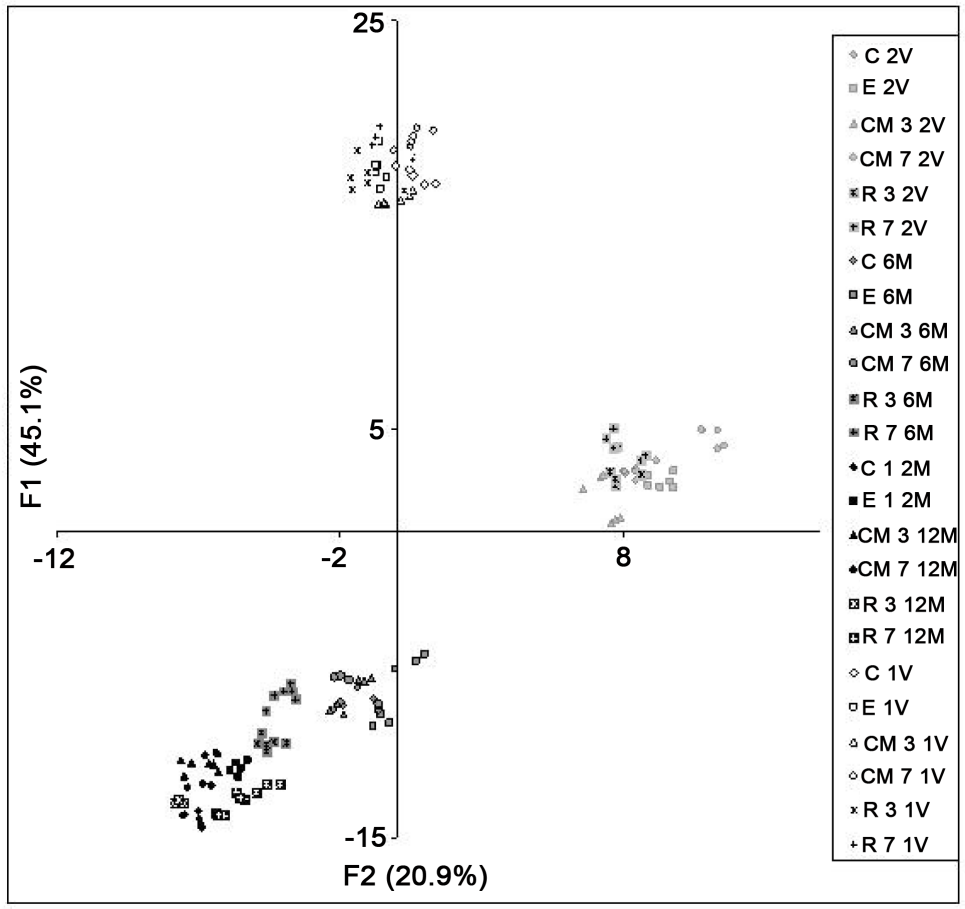

(a)

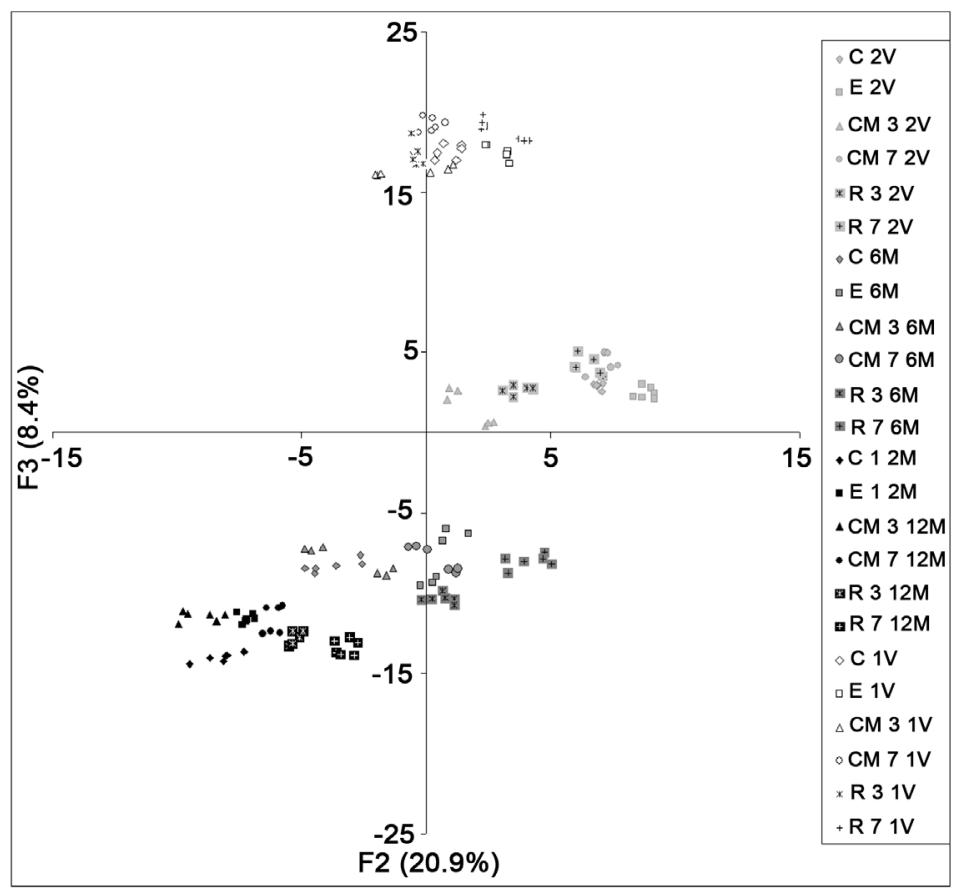

(b)

Figure 5. (a) Scatter diagram: sample distribution on the plane defined by the two first principal factors (F1 and F2), and (b) Scatter diagram: sample distribution on the plane defined by the first and third factor (F1 and F3). C-control; E-enzyme; CM-cryo-maceration; R-refrigeration at $5^{\circ} \mathrm{C} ; 3$ and 7 , duration time of maceration (days). $1 \mathrm{~V}$ and $2 \mathrm{~V}=$ wines from 0 months of bottling in the first and second vintage; $6 \mathrm{M}$ and $12 \mathrm{M}=$ wines after 6 and 12 months of bottling in the second vintage. 
were higher during the first six months of storage, in agreement with the high losses of phenolic components, specially catechins and tannins, as it was previously commented and showed (Figure 3).

According to the aforementioned comments, both F2 and F3 could be considered as storage factors. Furthermore, F3 was considered as a "maceration factor" due to the different scores of each group of wines by this factor. So, F3 scores indicated how, after six months of storage, the wines showed the maximum variability (maximum dispersion) corresponding with the higher stability of the phenolic fraction of macerated wines. After one year of storage, the differences among wines were generally reduced, but most of the macerated wines continued showing higher values of F3, F2 and even of F1, than the control wines (Figure 5(a) and Figure 5(b)). Then, it is possible to assert that 12 months maceration wines showed higher colour, phenolic and volatile stability than control ones.

\section{Conclusion}

It is difficult to determine the specific effect that pre-fermentative maceration techniques produce on the phenolic and volatile composition of Prieto Picudo wines. In spite of this uncertainty, it may be affirmed that maceration with enzymes is very effective in improving colour and phenolic contents, so as the content of some interesting volatile compounds. Cold maceration also can improve volatile and phenolic extraction but the final effects are more uncertain, and this type of techniques did not produce better results than enzymatic maceration.

\section{Acknowledgements}

The authors would like to acknowledge the financial support of INIA, through the Project of reference RTA2007-00074.

\section{Compliance with Ethics Requirements}

Mihaela Mihnea declares that she has no conflict of interest.

$M^{a}$ Luisa Gonzalez-SanJosé declares that she has no conflict of interest.

María Teresa Velasco-López declares that she has no conflict of interest.

María Dolores Rivero-Pérez declares that she has no conflict of interest.

Miriam Ortega-Heras declares that she has no conflict of interest.

Silvia Pérez-Magariño declares that she has no conflict of interest.

This article does not contain any studies with human or animal subjects.

\section{References}

[1] García-Muñoz, S., Asproudi, A., Cabello, F. and Borsa, D. (2011) Aromatic Characterization and Enological Potential of 21 Minor Varieties (Vitis vinifera L.). European Food Research and Technology, 233, 473-481. https://doi.org/10.1007/s00217-011-1538-1

[2] Gómez-Alonso, S., Fernandéz-González, M., Mena, A., Martiínez, J. and Garcia-Romero, E. (2007) Anthocyanin Profile of Spanish Vitis vinifera L. Red Grape Varieties in Danger of Extinction. Australian Journal of Grape and Wine Research, 13, 150-156. 
https://doi.org/10.1111/j.1755-0238.2007.tb00245.x

[3] Russo, G., Liuzzi, V. and D’Andrea, L. (2007) Evaluation, Conservation and Valorization of Local “Maruggio" Grapevine in Southern Italy. Acta Horticulturae, 754, 55-58.

https://doi.org/10.17660/ActaHortic.2007.754.5

[4] San-Juan, F., Cacho, J.F., Ferreira, V. and Escudero, A. (2012) 3-Methyl-2-Butene-1-Thiol: Identification, Analysis, Occurrence and Sensory Role of an Uncommon Thiol in Wine. Talanta, 99, 225-231. https://doi.org/10.1016/j.talanta.2012.05.043

[5] Álvarez-Pérez, J.M., Campo, E., San-Juan, F., Coque, J.J.R., Ferreira, V. and HernándezOrte, P. (2012) Sensory and Chemical Characterisation of the Aroma of Prieto Picudo Rosé Wines: The Differential Role of Autochthonous Yeast Strains on Aroma Profiles. Food Chemistry, 133, 284-292. https://doi.org/10.1016/j.foodchem.2012.01.024

[6] Martínez-Lapuente, L., Guadalupe, Z., Ayestarán, B., Ortega-Heras, M. and PérezMagarino, S. (2012) Sparkling Wines Produced from Alternative Varieties: Sensory Attributes and Evolution of Phenolics during Winemaking and Aging. American Journal of Enology and Viticulture, 64, 39-49. https://doi.org/10.5344/ajev.2012.12013

[7] Pérez-Magariño, S., Ortega-Heras, M., Martínez-Lapuente, L., Guadalupe, Z. and Ayestarán, B. (2013) Multivariate Analysis for the Differentiation of Sparkling Wines Elaborated from Autochthonous Spanish Grape Varieties: Volatile Compounds, Amino Acids and Biogenic Amines. European Food Research and Technology, 236, 827-841. https://doi.org/10.1007/s00217-013-1934-9

[8] Flanzy, C. (2000) Enología: Fundamentos científicos y tecnológicos. Mundi-Prensa, Madrid.

[9] Canal-Llauberes, R.M. (1993) Enzymes in Winemaking. In: Fleet, G.H., Ed., Wine Microbiology and Biotechnology, Harwood Academic Publishers, UK, 477-506.

[10] Pérez-Magariño, S. and González-SanJosé, M.L. (2000) Effect of Pectolytic Enzymes on the Composition of White Grape Musts and Wines. Italian Journal of Food Science, 12, 153162.

[11] Pardo, F., Salinas, M.R., Alonso, G.L., Navarro, G. and Huerta, M.D. (1999) Effect of Diverse Enzyme Preparations on the Extraction and Evolution of Phenolic Compounds in Red Wines. Food Chemistry, 67, 135-142. https://doi.org/10.1016/S0308-8146(99)00080-1

[12] Revilla, I. and González-SanJosé, M.L. (2002) Multivariate Evaluation of Changes Induced in Red Wine Characteristics by the Use of Extracting Agents. Journal of Agricultural and Food Chemistry, 50, 4525-4530. https://doi.org/10.1021/jf020175n

[13] Zimman, A., Joslin, W.S., Lyon, M.L., Meier, J. and Waterhouse, A.L. (2002) Maceration Variables Affecting Phenolic Composition in Commercial-Scale Cabernet Sauvignon Winemaking Trials. American Journal of Enology and Viticulture, 53, 93-98.

[14] Bautista-Ortín, A.B., Martínez-Cutillas, A., Ros-García, J.M., López-Roca, J.M. and GómezPlaza, E. (2005) Improving Colour Extraction and Stability in Red Wines: The Use of Maceration Enzymes and Enological Tannins. International Journal of Food Science and Technology, 40, 867-878. https://doi.org/10.1111/j.1365-2621.2005.01014.x

[15] Revilla, I. and González-SanJosé, M.L. (2003) Addition of Pectolytic Enzymes: An Enological Practice Which Improves the Chromaticity and Stability of Red Wines. International Journal of Food Science and Technology, 38, 29-36. https://doi.org/10.1046/j.1365-2621.2003.00628.x

[16] Revilla, I. and González-SanJosé, M.L. (2003) Compositional Changes during the Storage of Red Wines Treated with Pectolytic Enzymes: Low Molecular-Weight Phenols and Flavan3-Ol Derivative Levels. Food Chemistry, 80, 205-214. 
https://doi.org/10.1016/S0308-8146(02)00255-8

[17] Wightman, J.D., Price, S.F., Watson, B.T. and Wrolstad, R.E. (1997) Some Effects of Processing Enzymes on Anthocyanins and Phenolics in Pinot Noir and Cabernet Sauvignon Wines. American Journal of Enology and Viticulture, 48, 39-48.

[18] Zent, J.B. and Inama, S. (1992) Influence of Macerating Enzymes on the Quality and Composition of Wines Obtained from Red Valpolicella Wine Grapes. American Journal of Enology and Viticulture, 43, 311-316.

[19] Ducasse, M.-A., Canal-Llauberes, R.-M., de Lumley, M., Williams, P., Souquet, J.-M., Fulcrand, H., Doco, T. and Cheynier, V. (2010) Effect of Macerating Enzyme Treatment on the Polyphenol and Polysaccharide Composition of Red Wines. Food Chemistry, 118, 369-376. https://doi.org/10.1016/j.foodchem.2009.04.130

[20] Gil, J. V. and Vallés, S. (2001) Effect of Macerating Enzymes on Red Wine Aroma at Laboratory Scale: Exogenous Addition or Expression by Transgenic Wine Yeasts. Journal of Agricultural and Food Chemistry, 49, 5515-5523. https://doi.org/10.1021/jf0013104

[21] Hernández-Orte, P., Guitart, A., Ferreira, V., Gracia, J. and Cacho, J. (1998) Effect of Maceration Time and the Addition of Enzymes on the Amino Acid Composition of Musts and Wines and Its Influence on Wine Aroma. Food Science and Technology International, 4, 407-418. https://doi.org/10.1177/108201329800400605

[22] Salinas, M.R., Garijo, J., Pardo, F., Zalacain, A. and Alonso, G.L. (2003) Color, Polyphenol, and Aroma Compounds in Rosé Wines after Prefermentative Maceration and Enzymatic Treatments. American Journal of Enology and Viticulture, 54, 195-202.

[23] Sánchez-Palomo, E., Díaz-Maroto, M.C. and Perez-Coello, M. (2005) Aroma Enhancement in Wines from Different Grape Varieties Using Exogenous Glycosidases. Food Chemistry, 92, 627-635. https://doi.org/10.1016/j.foodchem.2004.08.025

[24] Wrolstad, R.E., Wightman, J.D. and Durst, R.W. (1994) Glycosidase Activity of Enzyme Preparations Used in Fruit Juice Processing. Food Technology, 48, 90-98.

[25] Álvarez, I., Aleixandre, J.L., García, M.J. and Lizama, V. (2006) Impact of Prefermentative Maceration on the Phenolic and Volatile Compounds in Monastrell Red Wines. Analytica Chimica Acta, 563, 109-115. https://doi.org/10.1016/j.aca.2005.10.068

[26] De Santis, D. and Frangipane, M.T. (2010) Effect of Prefermentative Cold Maceration on the Aroma and Phenolic Profiles of a Merlot Red Wine. Italian Journal of Food Science, 22, 47-53.

[27] Heatherbell, D., Dicey, M., Goldsworthy, S. and Vanhanen, L. (1997) Effect of Pre-Fermentation Cold Maceration on the Composition, Colour and Flavour of Pinot Noir Wine. Proceedings of the New Zealand Grape and Wine Symposium, 30-42.

[28] Kelebek, H., Selli, S. and Canbas, A. (2010) Effect of Cold Maceration Treatment on Anthocyanins in Red Wine Production of Öküzgözü Grapes. Tarim Bilimleri Dergisi, 16, 287-294.

[29] Parenti, A., Spugnoli, P., Calamai, L., Ferrari, S. and Gori, C. (2004) Effects of Cold Maceration on Red Wine Quality from Tuscan Sangiovese Grape. European Food Research and Technology, 218, 360-366. https://doi.org/10.1007/s00217-003-0866-1

[30] Petrozziello, M., Guaita, M., Motta, S., Panero, L. and Bosso, A. (2011) Analytical and Sensory Characterization of the Aroma of "Langhe D.O.C. Nebbiolo" Wines: Influence of the Prefermentative Cold Maceration with Dry Ice. Journal of Food Science, 76, C525-C534. https://doi.org/10.1111/j.1750-3841.2011.02145.x

[31] Herjavec, S., Jeromel, A., Prusina, T. and Maslov, L. (2008) Effect of Cold Maceration Time on Žilavka Wines Composition. Journal of Central European Agriculture, 9, 505-510. 
[32] OIV (1990) Compendium of International Methods of Analysis of Wines and Musts. Office International de la Vigne et du Vin, Paris.

[33] García Barceló, J. (1990) Analytic Techniques for Wines. GAB, Barcelona, 10-11.

[34] Mazza, G., Fukumoto, L., Delaquis, P., Girard, B. and Ewert, B. (1999) Anthocyanins, Phenolics, and Color of Cabernet Franc, Merlot, and Pinot Noir Wines from British Columbia. Journal of Agricultural and Food Chemistry, 47, 4009-4017. https://doi.org/10.1021/jf990449f

[35] Ribéreau-Gayon, P. and Stonestreet, E. (1965) Determination of Anthocyanins in Red Wine. Bulletin de la Societe Chimique de France, 9, 2649-2652.

[36] Glories, Y. (1984) The Color of Red Wines. Connaisance de la Vigne et du Vin, 18, 195-217.

[37] Pérez-Magariño, S. and González-SanJosé, M.L. (2004) Evolution of Flavanols, Anthocyanins, and Their Derivatives during the Aging of Red Wines Elaborated from Grapes. Journal of Agricultural and Food Chemistry, 52, 1181-1189. https://doi.org/10.1021/jf035099i

[38] Ortega-Heras, M., González-SanJosé, M.L. and Beltrán, S. (2002) Aroma Composition of Wine Studied by Different Extraction Methods. Analytica Chimica Acta, 458, 85-93. https://doi.org/10.1016/S0003-2670(01)01526-4

[39] Rivero-Pérez, M.D., Muñiz, P. and González-SanJosé, M.L. (2007) Antioxidant Profile of Red Wines Evaluated by Total Antioxidant Capacity, Scavenger Activity, and Biomarkers of Oxidative Stress Methodologies. Journal of Agricultural and Food Chemistry, 55, 54765483. https://doi.org/10.1021/jf070306q

[40] Kelebek, H., Canbas, A., Cabaroglu, T. and Selli, S. (2007) Food Chemistry Improvement of Anthocyanin Content in the cv. Öküzgözü by Using Pectolytic Enzymes. Food Chemistry, 105, 334-339. https://doi.org/10.1016/j.foodchem.2006.11.068

[41] Ortega-Heras, M., Pérez-Magariño, S. and González-SanJosé, M.L. (2012) Comparative Study of the Use of Maceration Enzymes and Cold Pre-Fermentative Maceration on Phenolic and Anthocyanic Composition and Colour of a Mencía Red Wine. LWT-Food Science and Technology, 48, 1-8. https://doi.org/10.1016/j.lwt.2012.03.012

[42] Takayanagi, T., Sato, M., Hanamure, K., Okuda, T. and Yokotsuka, K. (1997) Effect of Addition of Enzymes to Merlot Must on Color of Resulting Red Wine. American Journal of Enology and Viticulture, 48, 384-385.

[43] Couasnon, M.B. (1999) Une nouvelle technique: La maceration préfermentaire à froidextraction á la neige carbonique $\mathrm{l}^{\text {re }}$ partie: Résultats oenologiques. Revue dés Oenologues et des Techniques Vitivinicoles et Oenologiques, 92, 26-30.

[44] Heredia, F.J., Escudero-Gilete, M., Hernanz, D., Gordillo, B., Meléndez-Martínez, A.J., Vicario, I.M. and González-Miret, M.L. (2010) Influence of the Refrigeration Technique on the Colour and Phenolic Composition of Syrah Red Wines Obtained by Pre-Fermentative Cold Maceration. Food Chemistry, 118, 377-383. https://doi.org/10.1016/j.foodchem.2009.04.132

[45] Soto Vázquez, E., Río Segade, S. and Orriols Fernández, I. (2010) Effect of the Winemaking Technique on Phenolic Composition and Chromatic Characteristics in Young Red Wines. European Food Research and Technology, 231, 789-802. https://doi.org/10.1007/s00217-010-1332-5

[46] Revilla, I. and González-Sanjosé, M.L. (2001) Evolution during the Storage of Red Wines Treated with Pectolytic Enzymes: New Anthocyanin Pigment Formation. Journal of Wine Research, 12, 183-197. https://doi.org/10.1080/09571260120106820

[47] Romero-Cascales, I., Fernández-Fernández, J.I., Ros-García, J.M., López-Roca, J.M. and 
Gómez-Plaza, E. (2008) Characterisation of the Main Enzymatic Activities Present in Six Commercial Macerating Enzymes and Their Effects on Extracting Colour during Winemaking of Monastrell Grapes. International Journal of Food Science and Technology, 43, 1295-1305. https://doi.org/10.1111/j.1365-2621.2007.01608.x

[48] Muñoz, O., Sepulveda, M. and Schwartz, M. (2004) Effects of Enzymatic Treatment on Anthocyanic Pigments from Grapes Skin from Chilean Wine. Food Chemistry, 87, 487-490. https://doi.org/10.1016/j.foodchem.2003.12.024

[49] Baiano, A., Terracone, C., Gambacorta, G. and La Notte, E. (2009) Phenolic Content and Antioxidant Activity of Primitivo Wine: Comparison among Winemaking Technologies. Journal of Food Science, 74, C258-C267. https://doi.org/10.1111/j.1750-3841.2009.01101.x

[50] Gómez-Míguez, M.J., González-Miret, M.L., Hernanz, D., Fernández, M.Á., Vicario, I.M. and Heredia, F.J. (2007) Effects of Prefermentative Skin Contact Conditions on Colour and Phenolic Content of White Wines. Journal of Food Engineering, 78, 238-245.

https://doi.org/10.1016/j.jfoodeng.2005.09.021

[51] Satora, P., Tarko, T., Duda-Chodak, A., Sroka, P., Tuszynski, T. and Czepielik, M. (2009) Influence of Prefermentative Treatments and Fermentation on the Antioxidant and Volatile Profiles of Apple Wines. Journal of Agricultural and Food Chemistry, 57, 11209-11217. https://doi.org/10.1021/jf9025053

[52] Sánchez-Palomo, E., Díaz-Maroto, M.C., González-Viñas, M.A., Soriano-Pérez, A. and Pérez-Coello, M.S. (2007) Aroma Profile of Wines from Albillo and Muscat Grape Varieties at Different Stages of Ripening. Food Control, 18, 398-403. https://doi.org/10.1016/j.foodcont.2005.11.006

[53] Rapp, A. and Versini, G. (1995) Influence of Nitrogen Compounds in Grapes on Aroma Compounds of Wines. Developments in Food Science, 37, 1659-1694. https://doi.org/10.1016/S0167-4501(06)80257-8

[54] Armada, L., Fernández, E. and Falqué, E. (2010) Influence of Several Enzymatic Treatments on Aromatic Composition of White Wines. LWT-Food Science and Technology, 43, 1517-1525. https://doi.org/10.1016/j.lwt.2010.06.009

[55] Kechagia, D., Paraskevopoulos, Y., Symeou, E., Galiotou-Panayotou, M. and Kotseridis, Y. (2008) Influence of Prefermentative Treatments to the Major Volatile Compounds of Assyrtiko Wines. Journal of Agricultural and Food Chemistry, 56, 4555-4563. https://doi.org/10.1021/jf073550q

[56] Mihnea, M., González-SanJosé, M.L., Ortega-Heras, M. and Pérez-Magariño, S. (2015) A Comparative Study of the Volatile Content of Mencía Wines Obtained Using Different Pre-Fermentative Maceration Techniques. LWT_Food Science and Technology, 64, 32-41. https://doi.org/10.1016/j.lwt.2015.05.024

[57] Kelebek, H., Canbas, A., Selli, S., Saucier, C., Jourdes, M. and Glories, Y. (2006) Influence of Different Maceration Times on the Anthocyanin Composition of Wines Made from Vitis vinifera L. cvs. Boğazkere and Öküzgözü. Journal of Food Engineering, 77, 1012-1017. https://doi.org/10.1016/j.jfoodeng.2005.08.032

[58] Bueno, J.E., Peinado, R., Moreno, J., Medina, M., Moyano, L. and Zea, L. (2003) Selection of Volatile Aroma Compounds by Statistical and Enological Criteria for Analytical Differentiation of Musts and Wines of Two Grape Varieties. Journal of Food Science, 68, 158-163. https://doi.org/10.1111/j.1365-2621.2003.tb14133.x

[59] García-Falcón, M.S., Pérez-Lamela, C., Martínez-Carballo, E. and Simal-Gándara, J. (2007) Determination of Phenolic Compounds in Wines: Influence of Bottle Storage of Young Red Wines on Their Evolution. Food Chemistry, 105, 248-259. https://doi.org/10.1016/j.foodchem.2006.11.006 
[60] Guadalupe, Z. and Ayestarán, B. (2008) Changes in the Color Components and Phenolic Content of Red Wines from Vitis vinifera L. cv. "Tempranillo" during Vinification and Aging. European Food Research and Technology, 228, 29-38. https://doi.org/10.1007/s00217-008-0902-2

[61] Losada, M.M. andrés, J., Cacho, J.F., Revilla, E. and López, J.F. (2011) Influence of Some Prefermentative Treatments on Aroma Composition and Sensory Evaluation of White Godello Wines. Food Chemistry, 125, 884-891. https://doi.org/10.1016/j.foodchem.2010.09.060

[62] Oliveira, J.M., Oliveira, P., Baumes, R.L. and Maia, O. (2008) Changes in Aromatic Characteristics of Loureiro and Alvarinho Wines during Maturation. Journal of Food Composition and Analysis, 21, 695-707. https://doi.org/10.1016/j.jfca.2008.08.002

[63] Pérez-Coello, M.S., González-Viñas, M.A., García-Romero, E., Díaz-Maroto, M.C. and Cabezudo, M.D. (2003) Influence of Storage Temperature on the Volatile Compounds of Young White Wines. Food Control, 14, 301-306.

https://doi.org/10.1016/S0956-7135(02)00094-4

\section{Submit or recommend next manuscript to OALib Journal and we will provide best service for you:}

- Publication frequency: Monthly

- 9 subject areas of science, technology and medicine

- Fair and rigorous peer-review system

- Fast publication process

- Article promotion in various social networking sites (LinkedIn, Facebook, Twitter, etc.)

- Maximum dissemination of your research work

Submit Your Paper Online: Click Here to Submit

Or Contact service@oalib.com 